Article

\title{
Urban Circular Policies and Employment through Greenfield FDI
}

\author{
Spyridon Stavropoulos ${ }^{1, *}$, Martijn J. Burger ${ }^{1}$ and Joke Dufourmont ${ }^{2}$ \\ 1 Department of Applied Economics and Erasmus Happiness Research Organization (EHERO), \\ Erasmus University, Rotterdam, Tinbergen Institute, P.O. Box 1738, 3000 DR Rotterdam, The Netherlands; \\ mburger@ese.eur.nl \\ 2 Circle Economy, Mauritskade 64, 1092 AD Amsterdam, The Netherlands; joke@circle-economy.com \\ * Correspondence: stavropoulos@ese.eur.nl
}

Received: 14 January 2020; Accepted: 13 February 2020; Published: 15 February 2020

check for updates

\begin{abstract}
This paper examines the association between circular strategies imposed by European cities on the attraction of greenfield foreign direct investment (FDI) and the creation of circular gross employment through greenfield FDI. We utilize a recently developed database of circular strategies employed by local authorities in 43 European cities with information on greenfield FDI in these cities and other city characteristics for the years 2016-2017. We find that urban circular policies are positively and significantly associated with the attraction of greenfield FDI-generated employment, where the effect is stronger for regulatory and economic instruments compared to soft instruments.
\end{abstract}

Keywords: circular employment; circular strategies; FDI; policy instruments

\section{Introduction}

Over the past years, the rise of the circular economy has received a considerable amount of attention. Economic processes of production, distribution and consumption become more circular when fewer or no unusable final components, and products and energy remain at the end of the production and consumption cycle [1]. A large body of the circular economy literature focuses on the minimization of wastes and the negative impacts of the production process, via savings in the share of material, labour, energy and capital entrenched in the product [2,3]. Central to the circular economy's rise are the utilization of renewable and reusable resources as energy and materials in an efficient way, the maximization of lifetimes through resource preservation from maintenance, repair and upgrades, and more intensive product use and reuse through the sharing economy. Indeed, in the circular economy, it is all about reducing, reusing, repairing, refurbishing, remanufacturing, repurposing, recycling and recovering [4].

However, in the circular economy discourse, there is attention on not only its environmental benefits but also on its opportunity as a new business model providing numerous employment opportunities [5-8]. Given the potential positive effect of the circular economy on employment creation, it is gaining more popularity among local policy makers, although it is believed that the economic benefits of the transition to a circular economy are difficult to prove and identify vis-à-vis other (linear) modes of production and consumption [2,9]. To this end, local governments progressively utilize policies to improve the attractiveness of the local environment for circular economic activities. These policies can range from incentive-based economic policies, such as subsidies, grants and taxes, to provision of legal frameworks that facilitate secondary material use and collaboration platforms. However, to what extent these policies are conducive for the attraction of circular projects and employment generation remains unclear. 
In this study, we examine the relationship between the circular economy policies of cities and attraction of employment through greenfield foreign direct investment (FDI), where it is believed that urban circular policies strengthen cities' competitiveness. Greenfield FDI generally is accepted as an important source of financing and technology transfer, know-how between countries, and a source of job creation. As firms are assumed to invest in locations that yield the greatest benefits, location decisions clearly reflect locational competitive advantage, whereby more competitive locations generally receive more investments [10]. To examine the relationship between urban circular policies and FDI, we utilize a recently developed dataset including information on which circular strategies are employed by which local authorities in 43 European cities. The circular strategy information was obtained from both secondary sources (websites, public data) as well as interviews with experts from local municipalities. Subsequently, we tested to what extent the presence of circular strategies is associated with attracting greenfield FDI projects and employment to cities.

Building on studies that have examined the relationship between greenfield FDI and local and regional policies (e.g. [11-13]), to the best of our knowledge, this is the first study that examines the employment effects of circular economic policies and the relationship between these policies and the attraction of greenfield FDI. The remainder of this article is organized as follows: Section 2 explains the data collection and econometric framework, while Section 3 presents the results and Section 4 concludes the paper.

\section{Data and Methodology}

The data used in this study span the period 2016-2017 and cover 43 European cities. The cities were selected based on city size and inclusion in the Euromonitor Passport database from which we derive our control variables. Below we discuss the independent variables, dependent variable, control variables and estimation strategy used in this study.

\subsection{Independent Variable: Urban Circular Policies}

In our study, policy instruments are defined as tools for governments to intervene in an economy and society, with the intention of achieving behaviour change as an outcome [14]. On a high level, there are three general categories of public policy instruments: sticks (regulation), carrots (economic means) and sermons (information) [15]. These can respectively also be described as regulatory, economic and financial and soft instruments. Regulatory instruments consist of both regulation and legislation; economic instruments consist of fiscal frameworks, economic frameworks and direct financial support; and soft instruments consist of knowledge, advice and information, collaboration platforms and infrastructure and governance. Currently, this taxonomy constitutes one of the most accepted divisions of policy instruments in the literature and this division constitutes the basis for the policy framework that we developed for our analysis.

To obtain information on urban circular policy instruments at the city level, we obtained data from cities' municipal websites, where we searched for information about circular economy policy. Municipalities with little relevant information on their website were approached via email or over the phone with requests for further information on circular economy (CE) policy. For every European city in the Passport database, their websites were searched for CE policy information, and three closely related themes: waste management, sustainability and environment protection and energy and climate change mitigation. For each city, an inventory was made of the different urban circular polices, classified as regulatory, financial or soft.

In our study, we assume that the greater variety of circular policy instruments used by city governments, the more successful a city will be in attracting employment through greenfield FDI. Table 1 provides an overview of the number of instruments by type for the 43 cities in our database. As can be observed, cities differ considerably in the number of circular strategies they pursue. Where Amsterdam, Barcelona and Paris use 20 or more different policy instruments, several cities in Central and Eastern Europe (e.g., Bratislava, Bucharest, Prague and Sarajevo) pursue only one or two. Table A1 
summarizes the list of cities, the consulted websites and findings per city, while Table A2 provides a detailed taxonomy of the different policy instruments.

Table 1. Overview number of circular policy instruments per city.

\begin{tabular}{|c|c|c|c|c|}
\hline Destination City & Number of Instruments & Regulatory & Economic & Soft \\
\hline Amsterdam & 30 & 8 & 7 & 15 \\
\hline Antwerp & 10 & 7 & 2 & 1 \\
\hline Athens & 4 & 1 & 2 & 1 \\
\hline Barcelona & 20 & 5 & 3 & 12 \\
\hline Belgrade & 12 & 4 & 5 & 3 \\
\hline Berlin & 6 & 4 & 1 & 1 \\
\hline Birmingham & 18 & 4 & 4 & 10 \\
\hline Bratislava & 1 & 0 & 0 & 1 \\
\hline Brussels & 17 & 6 & 4 & 7 \\
\hline Bucharest & 2 & 1 & 0 & 1 \\
\hline Budapest & 13 & 5 & 5 & 3 \\
\hline Copenhagen & 15 & 2 & 4 & 9 \\
\hline Dublin & 6 & 4 & 1 & 1 \\
\hline Frankfurt am Main & 10 & 1 & 2 & 7 \\
\hline Geneva & 8 & 3 & 4 & 1 \\
\hline Glasgow & 9 & 3 & 3 & 3 \\
\hline Gothenburg & 19 & 4 & 7 & 8 \\
\hline Hamburg & 7 & 1 & 4 & 2 \\
\hline Helsinki & 4 & 2 & 1 & 1 \\
\hline Lisbon & 6 & 0 & 3 & 3 \\
\hline Ljubljana & 6 & 2 & 3 & 1 \\
\hline London & 19 & 4 & 5 & 10 \\
\hline Lyon & 11 & 2 & 3 & 6 \\
\hline Madrid & 12 & 2 & 3 & 7 \\
\hline Manchester & 7 & 1 & 1 & 5 \\
\hline Marseille & 6 & 1 & 2 & 3 \\
\hline Milan & 9 & 2 & 1 & 6 \\
\hline Munich & 3 & 0 & 1 & 2 \\
\hline Oslo & 12 & 5 & 6 & 1 \\
\hline Paris & 26 & 4 & 8 & 14 \\
\hline Prague & 1 & 1 & 0 & 0 \\
\hline Riga & 5 & 1 & 3 & 1 \\
\hline Rome & 1 & 0 & 1 & 0 \\
\hline Rotterdam & 16 & 3 & 5 & 8 \\
\hline Sarajevo & 2 & 0 & 0 & 2 \\
\hline Sofia & 13 & 4 & 6 & 3 \\
\hline Stockholm & 14 & 5 & 4 & 5 \\
\hline Tallinn & 8 & 2 & 2 & 4 \\
\hline Vienna & 12 & 3 & 2 & 7 \\
\hline Vilnius & 4 & 1 & 2 & 1 \\
\hline Warsaw & 4 & 1 & 2 & 1 \\
\hline Zagreb & 8 & 2 & 4 & 2 \\
\hline Zurich & 5 & 3 & 1 & 1 \\
\hline
\end{tabular}

Source: own calculations based on fDI Markets.

\subsection{Dependent Variable: Employment through Greenfield FDI}

In our study, we examine policy success using the number of greenfield investments in the circular economy weighted by employment created. Greenfield FDI encompasses investments in new physical projects, including expansions and co-location of activities. Joint ventures that represent new physical operations are also included. 
To empirically assess the employment effects of urban circular policies, we estimated discrete choice models using an initial sample of 47 firm-level greenfield location choices in the 43 European cities during the period 2016-2017, generating well over 1000 jobs. The greenfield data were obtained from the Financial Times fDI Markets database and were based on formal announcements by the media, financial information providers, industry organizations and publication companies (see also [10]). The data allow for functional differentiation and reveal that the majority of the investments involve business activities such as R\&D, manufacturing, sales, marketing and support and headquarters. There is no official minimum investment size, but investment projects creating fewer than five full-time jobs or involving a total investment of less than US\$1 million are uncommon (less than $5 \%$ of all investments in our database). In our study, we focus on investment in the environmental technology cluster, which most closely resembles our conceptualization of the circular economy. This cluster contains investments of firms that provide for the alternative and renewable energy sector, recycling, environmental control systems and environmental services. These not only involve firms that are active in the circular economy but also firms that enable and support it. Please note that we do not focus on greenfield investments before 2016, as many of those urban circular policies do not have information on when they started. In this fashion, we ensure that the policies were in place at the moment the investment decision was made, to avoid considerable endogeneity problems. For all investments, we have the number of jobs created. (Please note that some of the investment size data are estimated by fDI Markets rather than directly observed.) This variable will be used as weight in our location decision analysis.

Table 2 provides an overview of the distribution of greenfield FDI in the environmental technology cluster across the 43 cities in our study. This distribution is highly skewed, as less than $50 \%$ of the cities in the sample received investments related to environmental technology. In terms of sectoral division, most investments were related to alternative and renewable energy (30\%); engineering, technical and environmental consultancy services (23\%); manufacturing of electric equipment and components (19\%); and software and ICT services (11\%). Most often, firms related to the environmental technology cluster invested in Paris (13\%), Dublin $(8 \%)$ and London $(8 \%)$, while most new employment was generated in Stockholm (19\%), Dublin (15\%) and Budapest (15\%). Typically, investments in subsidiaries focusing on manufacturing, R\&D, recycling and electricity generation created more jobs than investments whose main activity was sales and marketing.

Table 2. Number of projects and jobs created through greenfield FDI by city, 2016-2017.

\begin{tabular}{ccc}
\hline City & Employment Created & Number of Projects \\
\hline Amsterdam & 14 & 2 \\
Antwerp & 34 & 1 \\
Belgrade & 20 & 2 \\
Berlin & 15 & 1 \\
Budapest & 150 & 1 \\
Copenhagen & 5 & 2 \\
Dublin & 155 & 4 \\
Frankfurt am Main & 8 & 2 \\
Glasgow & 17 & 3 \\
Hamburg & 8 & 2 \\
Helsinki & 16 & 2 \\
Lisbon & 14 & 2 \\
London & 58 & 4 \\
Lyon & 17 & 3 \\
Madrid & 75 & 4 \\
Munich & 4 & 1 \\
Paris & 63 & 6 \\
Rotterdam & 91 & 2 \\
Stockholm & 195 & 2 \\
Vilnius & 70 & 1 \\
\hline
\end{tabular}

Source: own calculations based on fDI Markets. 


\subsection{Control Variables}

In our empirical analysis, we controlled for several factors that may confound the relationship between urban circular policies and greenfield investments in environmental technology in European cities. In line with the previous literature on the location decisions of multinationals, we considered three types of factors related to city attractiveness: (1) demand factors, (2) costs of labour and (3) agglomeration and following behaviour. All control variables were obtained from the Euromonitor Passport database, except for the previous investment variable, for which we used information from the fDI Markets database. A short description of the control variables can be found in Table 3, while summary statistics are provided in Table 4.

Table 3. Description of variables.

\begin{tabular}{|c|c|}
\hline VARIABLES & Description \\
\hline Regulatory Instruments & Number of regulatory and legislative circular policy instruments a city uses. \\
\hline Soft Instruments & Number of soft circular policy instruments a city uses. \\
\hline Ln GDP & Natural logarithm of GDP. \\
\hline GDP Growth & Growth in GDP over the past year. \\
\hline Unemployment Rate & Percentage of the economically active population that is unemployed. \\
\hline Ln Population Density & Natural logarithm of population per square kilometer. \\
\hline Ln Previous Investments & $\begin{array}{l}\text { Natural logarithm of number of jobs generated through greenfield FDI in environmental technology } \\
\text { in } 2012-2015 \text { period. }\end{array}$ \\
\hline
\end{tabular}

Table 4. Summary statistics of cities in sample.

\begin{tabular}{cccccc}
\hline VARIABLES & N & mean & sd & min & max \\
\hline Number of Instruments & 43 & 9.79 & 6.67 & 1 & 30 \\
Regulatory Instruments & 43 & 2.65 & 1.96 & 0 & 8 \\
Economic Instruments & 43 & 2.95 & 1.03 & 0 & 8 \\
Soft Instruments & 43 & 4.19 & 3.90 & 0 & 15 \\
Ln GDP & 43 & 11.30 & 1.09 & 7.89 & 13.71 \\
GDP Growth & 43 & 2.47 & 1.63 & -0.70 & 7.30 \\
Ln Unit Wage Costs & 43 & -0.56 & 1.072 & -2.38 & 0.28 \\
Share Higher Education & 43 & 0.24 & 0.07 & 0.09 & 0.37 \\
Unemployment Rate & 43 & 0.08 & 0.05 & 0.03 & 0.23 \\
Ln Population Density & 43 & 6.25 & 0.78 & 4.40 & 7.69 \\
Ln Previous Investments & 43 & 3.03 & 2.15 & 0 & 6.30 \\
\hline
\end{tabular}

\subsection{Estimation Strategy}

The location decisions of firms and related new employment creation are often analysed using discrete choice models [16], and the most frequently used is the conditional logit model [17]. This model assumes that each firm faces a set of alternative locations in which it can invest and create new employment, with each firm comparing their attributes, including the local policies regarding stimulation of the circular economy. Hence, each location decision is viewed as the outcome of a discrete choice among a set of alternatives. It is assumed that a profit-maximizing firm will choose to locate its new subsidiary in a particular city if, and only if, this decision maximizes the expected future investment profits [18]. In our model, we use the number of jobs created as a weight variable in our discrete choice model, so large investments gain more importance in the regression analysis.

However, the conditional logit model has restrictive assumptions with regard to substitution patterns across alternative choice options. This problem is known as the violation of the independence of irrelevant alternatives (IIA) and is common in choice sets with many alternatives. Not accounting for IIA, assumption violations can result in inconsistent and biased estimates. Accordingly, we use a 
mixed logit estimation, allowing for random taste variation and unrestricted substitution patterns in our discrete choice model [11,13].

\section{Results}

Table 5 presents the results of the association between urban circular strategies and the propensity to invest weighted by the number of jobs created. We estimate 5 models, model 1 is the general mixed logit model, where no distinction between the different policies has been made, followed by models 2 to 4 where each policy is treated individually. Finally, in model 5 all three policies are included. In all the mixed logit models, the coefficients for GDP, wage, population density and previous investments are given in a log-normal distribution, while the rest of the coefficients are normally distributed. In general, the coefficients in the models in Table 5 have the expected signs, and the estimates are fairly consistent across models in terms of signs and significance. As expected, investment projects have a higher probability to be allocated in cities with higher GDP and human capital. The main finding of this analysis is that there is a positive and significant relationship between the number of circular policies a city has and employment generated through greenfield FDI. In terms of policies, the effect of regulatory instruments is higher compared to the economic and soft instruments. The least popular effect is for soft instruments. This may be surprising, but there is a plausible explanation.

Table 5. Results of the mixed logit model on the propensity to invest weighted by employment.

\begin{tabular}{|c|c|c|c|c|c|}
\hline VARIABLES & Model 1 & Model 2 & Model 3 & Model 4 & Model 5 \\
\hline Number of Instruments & $\begin{array}{c}0.072^{* * *} \\
(0.005)\end{array}$ & & & & \\
\hline Regulatory Instruments & & $\begin{array}{c}0.415^{* * *} \\
(0.024)\end{array}$ & & & $\begin{array}{c}0.406^{* * *} \\
(0.028)\end{array}$ \\
\hline Economic Instruments & & & $\begin{array}{c}0.169^{* * *} \\
(0.014)\end{array}$ & & $\begin{array}{c}0.160^{* * *} \\
(0.031)\end{array}$ \\
\hline Soft Instruments & & & & $\begin{array}{c}0.064^{* * *} \\
(0.009)\end{array}$ & $\begin{array}{c}-0.036^{* *} \\
(0.013)\end{array}$ \\
\hline Ln GDP & $\begin{array}{c}0.740^{* * *} \\
(0.069)\end{array}$ & $\begin{array}{c}0.633^{* * *} \\
(0.057)\end{array}$ & $\begin{array}{c}0.885^{* * *} \\
(0.068)\end{array}$ & $\begin{array}{c}0.880 * * * \\
(0.072)\end{array}$ & $\begin{array}{c}0.834^{* * *} \\
(0.088)\end{array}$ \\
\hline GDP Growth & $\begin{array}{l}-0.029 \\
(0.042)\end{array}$ & $\begin{array}{l}-0.053 \\
(0.039)\end{array}$ & $\begin{array}{c}0.004 \\
(0.043) \\
\end{array}$ & $\begin{array}{l}-0.066 \\
(0.045)\end{array}$ & $\begin{array}{c}0.044 \\
(0.049)\end{array}$ \\
\hline Ln Unit Wage Costs & $\begin{array}{c}0.633^{* * *} \\
(0.096)\end{array}$ & $\begin{array}{c}0.312^{* * * *} \\
(0.102)\end{array}$ & $\begin{array}{c}0.765^{* * * *} \\
(0.100)\end{array}$ & $\begin{array}{c}0.638^{* * *} \\
(0.079)\end{array}$ & $\begin{array}{c}0.837 * * * \\
(0.168)\end{array}$ \\
\hline \% Employees Higher Education & $\begin{array}{c}2.921^{* * *} \\
(0.448)\end{array}$ & $\begin{array}{c}3.766^{* * *} \\
(0.488)\end{array}$ & $\begin{array}{c}1.973^{* * *} \\
(0.507)\end{array}$ & $\begin{array}{c}3.542 * * * \\
(0.442)\end{array}$ & $\begin{array}{c}2.434^{* * *} \\
(0.631)\end{array}$ \\
\hline Unemployment Rate & $\begin{array}{l}-0.708 \\
(1.138)\end{array}$ & $\begin{array}{c}0.919 \\
(1.211)\end{array}$ & $\begin{array}{l}-0.845 \\
(0.967)\end{array}$ & $\begin{array}{c}0.131 \\
(0.960)\end{array}$ & $\begin{array}{c}1.035 \\
(1.553)\end{array}$ \\
\hline Ln Population Density & $\begin{array}{c}-0.937^{* * *} \\
(0.054)\end{array}$ & $\begin{array}{c}-0.903^{* * *} \\
(0.058)\end{array}$ & $\begin{array}{c}-0.844^{* * *} \\
(0.058)\end{array}$ & $\begin{array}{c}-0.902 \text { *** } \\
(0.057)\end{array}$ & $\begin{array}{c}-0.942 \text { *** } \\
(0.064)\end{array}$ \\
\hline Ln Prev. FDI Env. Technology & $\begin{array}{c}0.012 \\
(0.019)\end{array}$ & $\begin{array}{c}0.102^{* * *} \\
(0.020)\end{array}$ & $\begin{array}{c}0.016 \\
(0.020)\end{array}$ & $\begin{array}{l}-0.027 \\
(0.020)\end{array}$ & $\begin{array}{c}0.146^{* * *} \\
(0.022)\end{array}$ \\
\hline Number of jobs & 1029 & 1029 & 1029 & 1029 & 1029 \\
\hline Number of investment decisions & 47 & 47 & 47 & 47 & 47 \\
\hline Number of cities & 43 & 43 & 43 & 43 & 43 \\
\hline
\end{tabular}

Robust standard errors in parentheses; ${ }^{* *} p<0.01,{ }^{* *} p<0.05$. Random components of the coefficients are not reported. 
When we re-run our analysis on the number of projects also using a mixed logit estimation, we observe a particularly strong association between the number of policy instruments and larger investment projects (these results are available upon request), while for small investments, only soft instruments seem to be important for location decision. One explanation that needs further exploration is that small investments mainly concern sales and marketing activities, which are not truly affected by legislative and regulatory frameworks and are often not eligible for subsidies or other forms of economic support. These findings have to be treated cautiously as we were not able to find other studies addressing the relationship between circular policies and circular FDI.

\section{Concluding Remarks}

With increasing attention on the circular economy, it is interesting to know whether circular economic policies generate not only environmental benefits but also economic benefits. In our study, we examined location choices of firms that employ circular activities-defined as being active in the environmental technology cluster. We found that urban circular policies are positively and significantly associated with the attraction of greenfield FDI-generated employment, where the carrots (economic instruments) and sticks (regulatory instruments) seem to have a stronger effect than the sermons (soft instruments). The lower relative importance of soft instruments compared to economic and regulatory instruments can be explained by existing cultural barriers to the CE. According to Kirchherr et al. [4], particularly the lack of consumer interest and awareness as well as hesitant company culture regarding the potential of the CE slow down the rise of the circular economy.

Does this mean that local governments have to focus on regulatory and economic instruments to foster the CE? On the one hand, the lower effectiveness of soft instruments indicates that money might be better spent on providing subsidies for the $\mathrm{CE}$ and increasing taxes or even banning completely economic actions that are harmful to the environment rather than on advice and information, collaboration platforms and infrastructure and governance. At the same time, the harmony between economic, social and ecological development is crucial towards to a more CE economy [19]. Improving the effectiveness of soft instruments is, however, difficult since it requires cultural change. To create awareness and wide support for the $\mathrm{CE}$, it is first of all important that prominent administrators and politicians within local governments make a case for the transition towards the $\mathrm{CE}$ and install government employees who are specifically concerned with communication and connecting people within the CE. Monitoring CE development can also help to improve visibility and effectiveness of soft instruments as well. Monitoring does not only help to examine how the CE locally develops and whether specific interventions in policy ultimately lead to CE development, but also helps to create more awareness about the CE among the population. To find out how to best organize these governance structures to improve the effectiveness of these soft instruments [20], more research is, however, needed.

Author Contributions: For research articles with several authors, a short paragraph specifying their individual contributions must be provided. The following statements should be used "Conceptualization, S.S., M.J.B. and J.D.; methodology, S.S., and M.J.B.; software, S.S.; validation, S.S., M.J.B. and J.D.; formal analysis, S.S.; investigation, S.S., and J.D.; resources, S.S., and J.D; data curation, S.S., and J.D.; writing—original draft preparation, S.S., and M.J.B.; writing-review and editing, S.S., and M.J.B.; visualization, S.S.; supervision, M.J.B.; project administration, M.J.B., and J.D.; funding acquisition, M.J.B., and J.D.. All authors have read and agreed to the published version of the manuscript."

Funding: This research was funded by the Goldschmeding Foundation for People, Work and Economy, project name "Circle Cities Dashboard"

Conflicts of Interest: The authors declare no conflict of interest. 


\section{Appendix A}

Table A1. List of cities, consulted websites and findings per city highlighted by " $x$ ".

\begin{tabular}{|c|c|c|c|c|c|c|c|}
\hline $\begin{array}{l}\text { Cities Passport } \\
\text { Database }\end{array}$ & Municipality Website & $\begin{array}{l}\text { Circular } \\
\text { Economy }\end{array}$ & Sustainability & $\begin{array}{c}\text { Waste } \\
\text { Management }\end{array}$ & $\begin{array}{c}\text { Energy \& } \\
\text { Climate Change } \\
\text { Mitigation }\end{array}$ & $\begin{array}{l}\text { Invitation for } \\
\text { (Email) } \\
\text { Interview }\end{array}$ & $\begin{array}{c}\text { (Email) } \\
\text { Interview } \\
\text { Completed }\end{array}$ \\
\hline Amsterdam & https://www.amsterdam.n1/en/ & $\mathrm{x}$ & $\mathrm{x}$ & $\mathrm{x}$ & $\mathrm{x}$ & & \\
\hline Antwerp & https://www.antwerpen.be/nl/home & & $\mathrm{x}$ & $\mathrm{x}$ & $\mathrm{x}$ & & \\
\hline Athens & https://www.cityofathens.gr/en/citizens & & $\mathrm{x}$ & $\mathrm{x}$ & & & \\
\hline Barcelona & https://www.barcelona.cat/en/ & & $\mathrm{x}$ & $\mathrm{x}$ & $\mathrm{x}$ & & \\
\hline Belgrade & http://www.beograd.rs/en/ & & $\mathrm{x}$ & $\mathrm{x}$ & & $\mathrm{x}$ & \\
\hline Berlin & https://www.berlin.de/en/ & & $\mathrm{x}$ & $\mathrm{x}$ & $\mathrm{x}$ & $\mathrm{x}$ & $\mathrm{x}$ \\
\hline Birmingham & https://www.birmingham.gov.uk/ & & $\mathrm{x}$ & $\mathrm{x}$ & $\mathrm{x}$ & & \\
\hline Bratislava & http://www.region--bsk.sk/EN/default.aspx & & & & $\mathrm{x}$ & $\mathrm{x}$ & \\
\hline Brussels & https://www.brussels.be/ & $\mathrm{x}$ & $\mathrm{x}$ & & & & \\
\hline Bucharest & http://www.pmb.ro/common/site_map.php?sbm_id=24 & & $\mathrm{x}$ & & & $\mathrm{x}$ & \\
\hline Budapest & http://budapest.hu/Lapok/default.aspx & & $\mathrm{x}$ & & & $\mathrm{x}$ & $\mathrm{x}$ \\
\hline Copenhagen & https://international.kk.dk/ & & $\mathrm{x}$ & $\mathrm{x}$ & $\mathrm{x}$ & & \\
\hline Dublin & http://www.dublincity.ie/ & & $\hat{x}$ & $\hat{x}$ & $\hat{x}$ & & \\
\hline Geneva & http://www.ville--geneve.ch/welcome--geneva/ & & $\mathrm{x}$ & $\mathrm{x}$ & $\mathrm{x}$ & & \\
\hline Frankfurt Am Main & https://www.frankfurt.de/sixcms/detail.php?id=stadtfrankfurt_eval01.c.123086.en & & $\mathrm{x}$ & & $\mathrm{x}$ & $\mathrm{x}$ & \\
\hline Glasgow & https://www.glasgow.gov.uk/ & & & $\mathrm{x}$ & $\mathrm{x}$ & & \\
\hline Gothenburg & http://international.goteborg.se/organisation & & $\mathrm{x}$ & $\mathrm{x}$ & $\mathrm{x}$ & & \\
\hline Hamburg & https://www.hamburg.com/residents/settle/government/ & & & $\mathrm{x}$ & $\mathrm{x}$ & & \\
\hline Helsinki & https://www.hel.fi/helsinki/en & & $\mathrm{x}$ & & $\mathrm{x}$ & & \\
\hline Leeds & https://www.leeds.gov.uk/ & & & $\mathrm{x}$ & $\mathrm{x}$ & & \\
\hline Lisbon & http://www.cm--lisboa.pt/en & & $\mathrm{x}$ & $\mathrm{x}$ & & $\mathrm{x}$ & $\mathrm{x}$ \\
\hline Ljublijana & https://www.ljubljana.si/en/municipality/ & & $\mathrm{x}$ & $\mathrm{x}$ & $\mathrm{x}$ & $\mathrm{x}$ & $\mathrm{x}$ \\
\hline London & https://www.london.gov.uk/ & $\mathrm{x}$ & $\mathrm{x}$ & $\mathrm{x}$ & $\mathrm{x}$ & & \\
\hline Lyon & https://www.lyon.fr/ & & $\mathrm{x}$ & $\mathrm{x}$ & $\mathrm{x}$ & & \\
\hline Madrid & https://www.madrid.es/portal/site/munimadrid & & $\mathrm{x}$ & $\mathrm{x}$ & $\mathrm{x}$ & $\mathrm{x}$ & $\mathrm{x}$ \\
\hline Manchester & https://www.manchestergov.uk/ & & $\mathrm{x}$ & $\hat{x}$ & $\hat{x}$ & $\hat{n}$ & \\
\hline Marseille & http://www.marseille.fr/ & & $\mathrm{x}$ & $\mathrm{x}$ & & & \\
\hline Milan & https://www.comune.milano.it/wps/portal/ist/it & & & $\mathrm{x}$ & $\mathrm{x}$ & $\mathrm{x}$ & $\mathrm{x}$ \\
\hline Munich & https://www.muenchen.de/rathaus/home_en.html & & $\mathrm{x}$ & & $\mathrm{x}$ & $\mathrm{x}$ & $\mathrm{x}$ \\
\hline Oslo & https://www.oslo.kommune.no/english/\#gref & & $\mathrm{x}$ & $\mathrm{x}$ & $\mathrm{x}$ & & \\
\hline Paris & https://www.paris.fr/ & $\mathrm{x}$ & $\mathrm{x}$ & $\mathrm{x}$ & $\mathrm{x}$ & & \\
\hline Prague & http://www.praha.eu/jinp/en/index.html & & $\mathrm{x}$ & & & $\mathrm{x}$ & \\
\hline Riga & https://pasvaldiba.riga.lv/EN/Channels/Riga_Municipality/Riga_City_Council/default.htm & & $\mathrm{x}$ & & $\mathrm{x}$ & $\mathrm{x}$ & \\
\hline Rome & https://www.comune.roma.it/web/it/home.page & & & $\mathrm{x}$ & & $\hat{x}$ & \\
\hline Rotterdam & https://www.rotterdam.nl/english/ & $\mathrm{x}$ & $\mathrm{x}$ & $\mathrm{x}$ & $\mathrm{x}$ & & \\
\hline Sarajevo & $\mathrm{http}: / /$ sarajevo.ba/?lang=en & & & & $\mathrm{x}$ & $\mathrm{x}$ & \\
\hline Sofia & https://www.sofia.bg/web/sofia--municipality & & $\mathrm{x}$ & $\mathrm{x}$ & $\mathrm{x}$ & & \\
\hline Stockholm & https://international.stockholm.se/the--city--hall/ & & $\mathrm{x}$ & & $\mathrm{x}$ & & \\
\hline Tallinn & https://www.tallinn.ee/eng/ & & $\mathrm{x}$ & $\mathrm{x}$ & $\mathrm{x}$ & $\mathrm{x}$ & \\
\hline Vienna & https://www.wien.gv.at/english/administration/organisation/authority/municipality/city--council.html & & $\mathrm{x}$ & $\mathrm{x}$ & $\mathrm{x}$ & & \\
\hline Vilnius & https://vilnius.lt/en/ & & & $\mathrm{x}$ & $\mathrm{x}$ & $\mathrm{x}$ & \\
\hline Warsaw & http://www.um.warszawa.pl/en & & & & $\mathrm{x}$ & $\mathrm{x}$ & \\
\hline Zagreb & https://www.zagreb.hr/welcome/1979 & & $\mathrm{x}$ & $\mathrm{x}$ & $\mathrm{x}$ & $\mathrm{x}$ & \\
\hline Zurich & https://www.stadt--zuerich.ch/portal/en/index.html & & $\mathrm{x}$ & & $\mathrm{x}$ & & \\
\hline
\end{tabular}


Table A2. Taxonomy of circular economy policy instruments.

\begin{tabular}{|c|c|c|}
\hline Broad Category & Type of Instrument & Specific Instruments \\
\hline \multirow[t]{2}{*}{$\begin{array}{l}\text { Regulatory and } \\
\text { Legislative instruments }\end{array}$} & Regulation & $\begin{array}{l}\text { Strategy and Targets } \\
\text { Spatial planning } \\
\text { Environmental assessments and permits } \\
\text { Monitoring \& enforcement }\end{array}$ \\
\hline & Legislation & $\begin{array}{l}\text { Bans } \\
\text { Performance standards } \\
\text { Technology Standards } \\
\text { Labeling } \\
\text { Other legislations }\end{array}$ \\
\hline \multirow[t]{3}{*}{ Economic Instruments } & Fiscal Frameworks & $\begin{array}{l}\text { Positive price instruments } \\
\text { Negative price instruments }\end{array}$ \\
\hline & Direct financial support & $\begin{array}{l}\text { Grants } \\
\text { Circular procurements \& infrastructure } \\
\text { Debt financing }\end{array}$ \\
\hline & Economic frameworks & $\begin{array}{l}\text { Tradable permits } \\
\text { Extended producer responsibility } \\
\text { Public-private partnerships }\end{array}$ \\
\hline \multirow[t]{3}{*}{ Soft Instrument } & $\begin{array}{l}\text { Knowledge advice and } \\
\text { information }\end{array}$ & $\begin{array}{l}\text { Conducting research } \\
\text { Education programs } \\
\text { Information campaigns } \\
\text { Capacity building }\end{array}$ \\
\hline & $\begin{array}{l}\text { Collaboration platforms } \\
\text { and infrastructure }\end{array}$ & $\begin{array}{l}\text { Data \& information sharing platforms } \\
\text { Matchmaking platforms } \\
\text { Participatory platforms } \\
\text { Living labs }\end{array}$ \\
\hline & Governance & $\begin{array}{l}\text { Institutional design } \\
\text { Public partnerships } \\
\text { Voluntary agreements } \\
\text { Lobby }\end{array}$ \\
\hline
\end{tabular}

\section{References}

1. Van Oort, F.G.; Ramkumar, S.; Stavropoulos, S.; Burger, M.J.; Dufourmont, J.; Thissen, M. Putting the Circular Economy to Work: Measuring Gross Employment Effects in the Netherlands. 2018; 1996-2015.

2. Ellen Macarthur Foundation. Circular Economy Overview; Ellen Macarthur Foundation: Cowes, UK, 2018.

3. Winans, K.; Kendall, A.; Deng, H. The history and current applications of the circular economy concept. Renew. Sustain. Energy Rev. 2017, 68, 825-833. [CrossRef]

4. Kirchherr, J.; Reike, D.; Hekkert, M. Conceptualizing the circular economy: An analysis of 114 definitions. Resour. Conserv. Recycl. 2017, 127, 221-232. [CrossRef]

5. Bastein, T.; Roelofs, E.; Rietveld, E.; Hoogendoorn, A. Opportunities for a Circular Economy in the Netherlands; TNO: Delft, The Netherlands, 2013.

6. Burger, M.; Stavropoulos, S.; Ramkumar, S.; Dufourmont, J.; van Oort, F. The heterogeneous skill-base of circular economy employment. Res. Policy 2019. [CrossRef]

7. Ghisellini, P.; Cialani, C.; Ulgiati, S. A review on circular economy: The expected transition to a balanced interplay of environmental and economic systems. J. Clean. Prod. 2016, 114, 11-32. [CrossRef]

8. Murray, A.; Skene, K.; Haynes, K. The Circular Economy: An Interdisciplinary Exploration of the Concept and Application in a Global Context. J. Bus. Ethics 2017. [CrossRef]

9. Korhonen, J.; Honkasalo, A.; Seppälä, J. Circular Economy: The Concept and its Limitations. Ecol. Econ. 2018, 143, 37-46. [CrossRef]

10. Burger, M.J.; van der Knaap, B.; Wall, R.S. Revealed competition for greenfield investments between European regions. J. Econ. Geogr. 2013. [CrossRef] 
11. Basile, R.; Castellani, D.; Zanfei, A. Location choices of multinational firms in Europe: The role of EU cohesion policy. J. Int. Econ. 2008. [CrossRef]

12. Wren, C.; Jones, J. Assessing the regional impact of grants on fdi location: Evidence from U.K. Regional policy, 1985-2005. J. Reg. Sci. 2011. [CrossRef]

13. Burger, M.J.; Karreman, B.; van Eenennaam, F. The competitive advantage of clusters: Cluster organisations and greenfield FDI in the European life sciences industry. Geoforum 2015. [CrossRef]

14. Vedung, E. Carrots, Sticks, E Sermons: Policy Instruments $\mathcal{E}$ Their Evaluation; Transaction Publishers: Piscatawaynj, NJ, USA, 1998.

15. Bemelmans-Videc, M.L.; Rist, R.C.; Vedung, E. Carrots, Sticks and Sermons: Policy Instruments and Their Evaluation. In Comparative Policy Evaluation Series; Transaction Publishers: Piscatawaynj, NJ, USA, 2010.

16. Schmidheiny, K.; Brülhart, M. On the equivalence of location choice models: Conditional logit, nested logit and Poisson. J. Urban Econ. 2011. [CrossRef]

17. McFadden, D.L. Conditional logit analysis of qualitative choice behavior. In Frontiers in Econometrics; Zarembka, P., Ed.; Academic Press: New York, NJ, USA, 1973; pp. 105-142.

18. Long, J.S. Regression Models for Categorical and Limited Dependent Variables; Sage Publications: London, UK, 1997.

19. Raworth, K. Doughnut Economics: Seven Ways to Think Like a 21st-century Economist; Chelsea Green Publishing: White River Junction, VT, USA, 2017.

20. McDowall, W.; Geng, Y.; Huang, B.; Barteková, E.; Bleischwitz, R.; Türkeli, S.; Kemp, R.; Doménech, T. Circular economy policies in China and Europe. J. Ind. Ecol. 2017. [CrossRef]

(C) 2020 by the authors. Licensee MDPI, Basel, Switzerland. This article is an open access article distributed under the terms and conditions of the Creative Commons Attribution (CC BY) license (http://creativecommons.org/licenses/by/4.0/). 